\title{
Peran Juru Pantau Jentik dalam Sistem Kewaspadaan Dini Demam Berdarah Dengue di Indonesia
}

\section{The Role of Juru Pantau Jentik in Dengue Haemorrhagic Fever Early Warning System in Indonesia}

\section{Diana Andriyani Pratamawati}

Balai Besar Penelitian dan Pengembangan Vektor dan Reservoir Penyakit

\begin{abstract}
Abstrak
Program pencegahan dan pemberantasan demam berdarah dengue (DBD) telah berlangsung sekitar 43 tahun dan berhasil menurunkan angka kematian dari 41,3\% pada tahun 1968 menjadi $0,87 \%$ pada tahun 2010, tetapi belum berhasil menurunkan angka kesakitan. Bahkan, Indonesia menduduki urutan tertinggi kasus DBD di Association of Southeast Asian Nations (ASEAN) pada tahun 2010. Salah satu faktor belum efektifnya pencegahan DBD di Indonesia adalah masih lemahnya sistem kewaspadaan dini. Peran juru pantau jentik (jumantik) sangat penting dalam sistem kewaspadaan dini mewabahnya DBD karena berfungsi untuk memantau keberadaan dan menghambat perkembangan awal dari vektor penular DBD. Seiring masih tingginya angka kasus DBD di Indonesia, muncul pertanyaan bagaimana peran jumantik dalam sistem kewaspadaan dini DBD selama ini di Indonesia. Artikel ini mencoba menelaah masalah tersebut berdasarkan tinjauan pustaka. Secara umum, peran jumantik dinilai cukup berhasil dalam pencegahan $\mathrm{DBD}$, namun terdapat beberapa hal yang perlu menjadi bahan evaluasi.

Kata kunci: Jumantik, demam berdarah dengue, sistem kewaspadaan dini
\end{abstract}

\footnotetext{
Abstract

Programs of prevention and eradication of dengue hemorrhagic fever (DHF) has been around 43 years and managed to reduce mortality from $41,3 \%$ in 1968 to $0,87 \%$ in 2010 , but has not managed to reduce morbidity. Indonesia even ranked the highest of dengue cases in Association of Southeast Asian Nations (ASEAN) by the year 2010. One factor that made has not been effective dengue prevention in Indonesia is the early warning system is still weak. Jumantik role is very important in the early warning system outbreaks of dengue hemorrhagic fever because it serves to monitor the presence and inhibit the early development of vector-borne dengue fever. During the high number of dengue cases in Indonesia, question rouses how jumantik role in the dengue hemorrhagic fever early warning sys-
}

tem so far in Indonesia. This article takes a closer look based on a literature review. In general, the role of jumantik considered quite successful in preventing dengue hemorrhagic fever early warning system but nevertheless there are things that need to be evaluated.

Key words: Jumantik, dengue hemorrhagic fever, early warning system

\section{Pendahuluan}

Penyakit demam berdarah dengue (DBD) adalah penyakit menular yang diakibatkan oleh virus dengue dan disebarluaskan oleh nyamuk terutama spesies Aedes aegypti. World Health Organization (WHO) menggolongkan penyakit ini ke dalam penyakit infeksi baru yang sedang muncul dan meningkat karena semakin meluasnya sebaran geografis serta semakin meningkatnya jumlah penduduk yang terkena. Lebih dari 2,5 miliar penduduk dunia berisiko terkena penyakit DBD dengan mayoritas atau sekitar $70 \%$ populasi hidup di kawasan Asia Pasifik. ${ }^{1}$

Berdasarkan data Kementerian Kesehatan Republik Indonesia, sejak pertama kali ditemukan tahun 1968, Indonesia pernah mengalami kejadian luar biasa (KLB) DBD selama beberapa kali yaitu pada tahun 1973, 1977, 1978, 1983, 1988, 1996, 1998, 2007, dan 2009. Kasus KLB DBD yang paling tinggi selama kurun waktu sepuluh tahun terakhir adalah pada tahun 2009 dengan jumlah kasus sebanyak 154.855 dan jumlah penderita yang meninggal sebanyak 1.384 orang. Peningkatan jumlah kasus ini dua kali lipat lebih banyak bila dibandingkan

Alamat Korespondensi: Diana Andriyani Pratamawati, Balai Besar Penelitian dan Pengembangan Vektor dan Reservoir Penyakit, Jl. Hasanudin No. 123 Salatiga 50721, Hp.085643704228,e-mail: pratamawati@gmail.com 
dengan KLB DBD tahun 1998 sebanyak 72.133 dan penderita yang meninggal sebanyak 1.414 orang. 2,3

Berdasarkan kajian dari Kementerian Kesehatan RI diperoleh kesimpulan bahwa KLB DBD di Indonesia diakibatkan oleh beragam faktor. Pertama, pada dasarnya penyakit menular termasuk DBD masih endemik di beberapa wilayah karena terdapat vektor nyamuk hampir di seluruh pelosok tanah air serta adanya 4 sel tipe virus yang bersirkulasi sepanjang tahun. Hal ini menyebabkan sewaktu-waktu mungkin dapat terjadi KLB. Faktor kedua adalah lemahnya sistem kewaspadaan dini sehingga penanganan dan pengobatan kasus sebagai intervensi belum dilakukan sebagaimana mestinya. Ketiga, kemudahan alat transportasi memungkinkan pergerakan/perpindahan alat angkut, penumpang, bahan/barang, dan alat dari satu wilayah ke wilayah lain yang merupakan daerah endemik. Ketiga faktor tersebut didukung dengan masih rendahnya kesadaran masyarakat akan paradigma hidup sehat dan kesadaran pada kondisi lingkungan sekitar sebagai faktor risiko penyebaran penyakit. ${ }^{4}$

DBD merupakan penyakit berbasis lingkungan. Kepadatan penduduk sangat berpengaruh pada kejadian kasus DBD, semakin padat penduduk semakin tinggi kasus DBD di kota tersebut. Hal ini berkaitan dengan penyediaan infrastruktur yang kurang memadai seperti penyediaan sarana air bersih dan sarana pembuangan sampah sehingga terkumpul barang-barang bekas yang dapat menampung air dan menjadi tempat perkembangbiakan nyamuk Aedes sp, vektor penular DBD. Mobilitas masyarakat juga merupakan faktor risiko perpindahan virus DBD pada individu dari satu kota ke kota lain yang memengaruhi penyebaran penyakit DBD. Selain itu, adanya kebiasaan masyarakat menampung air untuk keperluan sehari-hari seperti menampung air hujan, menampung air sumur atau membeli air di penjual air sehingga bak mandi atau drum/tempayan jarang dikuras berpotensi sebagai tempat perkembangbiakan nyamuk. Ada pula kebiasaan masyarakat menyimpan barangbarang bekas tetapi kurang rajin memeriksa lingkungan terhadap adanya air yang tertampung di dalam tempat penampungan air (TPA) serta kurang melaksanakan kebersihan lingkungan. Akibatnya, anjuran 3M Plus (Menguras, Menutup, dan Mengubur Plus menaburkan larvasida, memelihara ikan pemakan jentik, serta pemakaian insektisida rumah tangga) untuk mencegah DBD belum terlaksana secara efektif. ${ }^{5}$ Kementerian Kesehatan RI telah menetapkan Program Nasional Penanggulangan DBD melalui Kepmenkes No. 581 Tahun 1992 yang terdiri dari 8 pokok program meliputi: surveilans epidemiologi dan penanggulangan KLB; pemberantasan vektor, penatalaksanaan kasus, penyuluhan, kemitraan dalam wadah kelompok kerja operasional (Pokjanal) DBD, peran serta masyarakat: juru pemantau jentik (jumantik), pelatihan, dan penelitian.
Sebagai langkah operasional, Kementerian Kesehatan telah menetapkan beberapa kegiatan pokok sebagai kebijakan dalam pengendalian penyakit DBD antara lain setiap terjadi kasus DBD dilakukan penyelidikan epidemiologi meliputi radius 100 meter dari rumah penderita. Apabila ditemukan bukti-bukti penularan yaitu adanya penderita DBD lain, ada 3 penderita demam atau ada faktor risiko yaitu ditemukan jentik maka dilakukan penyemprotan (fogging focus) dengan siklus 2 kali disertai larvasidasi dan gerakan Pemberantasan Sarang Nyamuk (PSN). Pusat kesehatan masyarakat (Puskesmas) melaksanakan kegiatan Pemeriksaan Jentik Berkala (PJB) 4 kali setahun untuk memonitor kepadatan jentik di wilayah tersebut. Penanggulangan DBD lebih mengutamakan pencegahan yaitu dengan melaksanakan PSN melalui 3M Plus dengan melibatkan masyarakat dan memfasilitasi terbentuknya tenaga jumantik. Untuk mendukung terlaksananya program pencegahan ini dibentuk kemitraan melalui wadah Pokjanal bersama lintas sektor lain. Selain itu, diadakan penyuluhan untuk masyarakat agar tetap waspada. ${ }^{5}$

Peran jumantik sangat penting dalam sistem kewaspadaan dini mewabahnya DBD karena berfungsi untuk memantau keberadaan dan menghambat perkembangan awal vektor penular DBD. Keaktifan kader jumantik dalam memantau lingkungannya diharapkan dapat menurunkan angka kasus DBD. Oleh karena itu, diperlukan upaya peningkatan keaktifan jumantik melalui motivasi yang dilakukan oleh dinas kesehatan. ${ }^{6}$ Senada dengan hal tersebut, penelitian yang dilakukan di Surakarta Jawa Tengah menunjukkan bahwa faktor yang memengaruhi upaya pencegahan DBD adalah tindakan masyarakat, tingkat pendidikan, informasi, dan partisipasi sosial yang menunjukkan angka signifikan terhadap pengaruh masyarakat dalam pencegahan DBD di wilayah Puskesmas II Surakarta. ${ }^{7}$ Salah satu faktor yang mendorong peningkatan kasus DBD adalah keterbatasan petugas kesehatan untuk melakukan penyuluhan secara berkesinambungan dan kepedulian masyarakat terhadap upaya pencegahan DBD melalui PSN sehingga diperlukan adanya peningkatan penyuluhan dari petugas kesehatan kapada masyarakat baik perorangan, keluarga, dan masyarakat. ${ }^{8}$

Kader jumantik merupakan kelompok kerja kegiatan pemberantasan penyakit DBD di tingkat desa dalam wadah Lembaga Ketahanan Masyarakat Desa (LKMD). Tujuan dibentuknya kader jumantik adalah untuk menggerakkan peran serta masyarakat dalam usaha pemberantasan penyakit $\mathrm{DBD}$, terutama dalam pemberantasan jentik nyamuk penular sehingga penularan penyakit DBD di tingkat desa dapat dicegah atau dibatasi. ${ }^{9}$

Program pencegahan dan pemberantasan DBD telah berlangsung lebih kurang 43 tahun dan berhasil menurunkan angka kematian dari 41,3\% pada tahun 1968 
menjadi $0,87 \%$ pada tahun 2010 , tetapi belum berhasil menurunkan angka kesakitan. Di Indonesia, sampai dengan bulan Agustus tahun 2011 tercatat 24.362 kasus dengan 196 kematian (case fatality rate, CFR: 0,80\%). ${ }^{5}$ Bahkan Indonesia menduduki urutan tertinggi kasus DBD di Association of Southeast Asian Nations (ASEAN) dengan jumlah kematian sekitar 1.317 orang pada tahun 2010. ${ }^{10}$ Salah satu faktor belum efektifnya pencegahan DBD di Indonesia adalah masih lemahnya sistem kewaspadaan dini. ${ }^{11}$ Berdasarkan latar belakang tersebut muncul pertanyaan bagaimana peran jumantik dalam sistem kewaspadaan dini DBD selama ini di Indonesia? Artikel ini mencoba mengkaji permasalahan tersebut berdasarkan tinjauan literatur.

\section{Pola Kinerja Jumantik di Indonesia}

Kader jumantik merupakan kelompok kerja kegiatan pemberantasan penyakit DBD di tingkat desa dalam wadah LKMD. ${ }^{9}$ Menurut pandangan masyarakat, jumantik adalah petugas khusus yang berasal dari lingkungan sekitar yang secara sukarela mau bertanggung jawab untuk malakukan pemantauan jentik nyamuk DBD Aedes aegypti di wilayahnya serta melakukan pelaporan ke kelurahan secara rutin dan berkesinambungan. ${ }^{12}$

Peran kader kesehatan dalam menanggulangi DBD antara lain, sebagai anggota PJB di rumah-rumah dan tempat umum; memberikan penyuluhan kepada keluarga dan masyarakat; mencatat dan melaporkan hasil PJB kepada kepala dusun atau puskesmas secara rutin minimal mingguan dan bulanan; mencatat dan melaporkan kasus kejadian DBD kepada rukun warga (RW), kepala dusun atau puskesmas; melakukan PSN dan pemberantasan DBD secara sederhana seperti pemberian bubuk abate dan ikan pemakan jentik. ${ }^{9}$

Susunan organisasi kader jumantik terdiri dari kader jumantik yang merupakan kelompok kerja kegiatan pemberantasan penyakit DBD dan kepala desa selaku ketua umum. Susunan organisasi kader jumantik disesuaikan dengan kondisi dan situasi serta kebutuhan setempat, berdasarkan ketentuan yang ada bahwa di dalam organisasi LKMD dapat dibentuk kelompok kerja (Pokja) yang hanya melaksanakan jenis kegiatan dari seksi yang sesuai dengan bidang, tugas, dan fungsinya. ${ }^{9}$ Tugas dan fungsi kader jumantik DBD antara lain, mengoordinasi kegiatan-kegiatan jumantik; memimpin dan menyelenggarakan pertemuan; menetapkan jadwal waktu pertemuan berkala; menetapkan langkah-langkah pemecahan masalah; melaporkan hasil kegiatan; menyiapkan penyelenggaraan pertemuan (undangan dan tempat pertemuan); menyiapkan laporan berkala kegiatan Pokja kepada ketua LKMD; menyiapkan bahan pertemuan, misalnya data-data hasil PJB; memberikan bimbingan teknis pelaksanaan pemeriksaan jentik; memberikan penyuluhan dan bimbingan teknis penyuluhan kepada para penyuluh; mencatat kegiatan-kegiatan penyuluhan dan lain-lain; melaksanakan pemeriksaan jentik di 30 rumah secara acak di tiap RW; sekurang-kurangnya tiap 3 bulan menyampaikan hasilnya kepada ketua LKMD; membantu pelatihan kader jumantik; merencanakan kegiatan masyarakat secara bersamasama untuk melaksanakan PSN; serta menyiapkan masyarakat dalam pelaksanaaan penanggulangan penyakit DBD. ${ }^{9}$

Pada praktiknya di masyarakat, jumantik mendapatkan pelatihan khusus jumantik dan tinggal di dekat wilayah pantau jentik nyamuk DBD. Pemantauan dilakukan satu kali dalam seminggu. Jika ditemukan jentik nyamuk maka petugas berhak memberi peringatan kepada penghuni/pemilik rumah untuk membersihkan atau menguras tempat penampungan air agar bersih dari jentik. Selanjutnya, jumantik menulis catatan dan laporan yang diperlukan untuk dilaporkan ke kelurahan dan kemudian dari kelurahan dilaporkan ke instansi terkait atau vertikal. ${ }^{12}$

Selain petugas jumantik, orang yang tinggal di sekitar suatu wilayah diwajibkan juga melakukan pengawasan/pemantauan jentik di wilayahnya. Kegiatan ini telah diintensifkan sejak tahun 1992 dan pada tahun 2000 dikembangkan menjadi 3M Plus. Teknik dasar 3M Plus yang telah disosialisasikan antara lain: 1) menutup adalah memberi tutup yang rapat pada tempat air ditampung seperti bak mandi, kendi, gentong air, botol air minum, dan tempat penampungan air lainnya; 2) menguras adalah membersihkan tempat yang sering dijadikan tempat penampungan air seperti kolam renang, bak mandi, ember air, tempat air minum, penampung air di belakang kulkas, penampungan air tetesan dispenser, dan tempat penampungan air lainnya; 3) mengubur adalah memendam di dalam tanah sampah plastik atau barang bekas yang memiliki potensi menampung air hujan sehingga dapat menjadi tempat nyamuk vektor DBD bertelur. ${ }^{12}$

Selain itu, ditambahkan kegiatan pencegahan meliputi menggunakan obat nyamuk/antinyamuk sesuai dosis dan petunjuk pemakaian pada kemasan; menggunakan kelambu saat tidur siang dan malam hari; menanam tanaman pengusir nyamuk seperti lavender, zodia; memelihara ikan yang dapat memakan jentik nyamuk pada kolam atau bak mandi; menghindari daerah gelap di dalam rumah agar tidak ditempati nyamuk dengan mengatur ventilasi dan pencahayaan; serta memberi bubuk larvasida pada tempat penampungan air yang sulit dibersihkan.

\section{Peran Jumantik dalam Sistem Kewaspadaan Dini DBD di Indonesia}

Di Indonesia, pada saat musim hujan populasi nya- 
muk meningkat meskipun saat musim kering populasinya tetap banyak oleh karena masyarakat memiliki kebiasaan menampung air di dalam bak air/drum terutama di daerah sulit air sehingga nyamuk dan jentik selalu ada sepanjang tahun. Kegiatan pemeriksaan jentik berjalan namun tidak menyeluruh karena keterbatasan tenaga. Puskesmas melaksanakan PJB, kader-kader jumantik melaksanakan pemeriksaan jentik seminggu sekali di lingkungannya, namun tidak tersedia dana operasional maupun biaya pengganti transpor bagi para kader jumantik sehingga kegiatan mengendur. ${ }^{5}$

Kunci pencegahan penyakit DBD adalah pengawasan yang ketat untuk pelaporan dini hasil pemantauan kepadatan vektor sehingga pengambilan tindakan tidak terlambat saat menerima laporan kasus dari lokasi wabah. Keberadaan jumantik memiliki peran vital dalam pemberantasan DBD karena bertugas memantau populasi nyamuk penular DBD dan jentiknya. Pemeriksaan jentik berkala dilakukan oleh jumantik yang bertugas melakukan kunjungan rumah setiap 3 bulan. Hasil yang didapat jumantik dilaporkan dalam bentuk Angka Bebas Jentik (ABJ) yaitu rasio antara jumlah rumah/bangunan yang tidak ditemukan jentik dengan jumlah rumah/ bangunan yang diperiksa dikali $100 \%$. ABJ merupakan indikator penyebaran Aedes aegypti. ABJ yang ditargetkan secara nasional mencapai lebih dari 95\%.11,13 $\mathrm{ABJ}$ sesungguhnya bukan jaminan akan adanya penurunan jumlah kasus karena bisa saja daerah berpotensi sarang nyamuk yang tersembunyi atau tidak terpantau seperti kaleng bekas di jalan, rumah kosong, lubang bambu/pohon, dan sebagainya. Oleh karena itu, pada saat survei jentik memerlukan ketelitian dalam memeriksa tempat-tempat perkembangbiakan nyamuk. ${ }^{14}$

Berdasarkan hasil penelitian di daerah Jakarta Utara disebutkan beberapa daerah melaporkan bahwa $\mathrm{ABJ}$ telah mencapai $90 \%$, bahkan ada pula yang mencapai 95\%. Namun pada kenyataannya, angka kasus penderita DBD masih tetap tinggi. Kenyataan tersebut bermakna angka kasus penderita DBD tidak semata-mata berhubungan langsung dengan ABJ. Berdasarkan kenyataan tersebut dapat diduga angka $\mathrm{ABJ}$ yang tinggi mungkin disebabkan oleh jumantik yang kinerjanya kurang baik. Salah satu indikatornya adalah jumantik kurang teliti dalam melakukan survei. Jumantik mungkin hanya memeriksa tempat penampungan air yang besar seperti bak mandi, ember, dan drum, sedangkan wadah yang kecil misalnya vas bunga, penampungan air di belakang kulkas, penampungan tetesan air conditioner (AC), dan penampungan tetesan dispenser tidak diperiksa. Tempat penampungan air di luar rumah seperti talang air, tangki air, botol bekas, kaleng, wadah plastik, dan sebagainya terkadang juga tidak diperiksa. Hal tersebut mengakibatkan lepasnya jentik Aedes aegypti dari pemeriksaan. Selain itu, sebagian pemilik rumah tidak mengijinkan rumahnya disurvei. Ada pula rumah atau bangunan yang dikunci karena tidak dihuni atau penghuninya sedang pergi sehingga terlewat dari pemeriksaan. ${ }^{15}$

Secara umum, peran jumantik dinilai cukup berhasil dalam pencegahan DBD, namun terdapat beberapa hal yang menjadi bahan evaluasi. Pengalaman di lapangan dalam melakukan evaluasi kinerja jumantik biasanya mereka tidak memberikan informasi yang cukup kepada masyarakat mengenai DBD dan pencegahannya. Motivasi kepada masyarakat juga jarang diberikan padahal, ini penting sekali untuk selalu diberikan dan diingatkan kepada masyarakat tentang pencegahan DBD. Kalau program ini berjalan dengan baik maka masyarakat akan memiliki pengetahuan yang cukup tentang DBD dan perilaku mereka terkontrol. Jumantik juga perlu melakukan pengawasan pada tanah kosong seperti kebun dan kuburan yang sering kali terlewati. Tempat-tempat seperti ini juga berpotensi menjadi tempat perkembangbiakan nyamuk Aedes aegypti. ${ }^{14}$

Pada beberapa daerah endemis DBD, program jumantik berperan cukup efektif dalam menurunkan kasus DBD. Salah satu daerah endemis yang memiliki kasus DBD tertinggi pada tahun 2011 adalah Provinsi Bali. ${ }^{5}$ Program jumantik cukup berperan dalam memantau kondisi lingkungan masyarakat di Kota Denpasar Bali. Ada petugas khusus yang bergerak untuk bekerja ekstra dalam upaya pencegahan DBD. Fokus utamanya adalah daerah perkotaan yang masyarakatnya cukup padat dan memiliki mobilitas tinggi. Program jumantik dengan tenaga khusus tersebut dijalankan dan digaji setiap bulan. Pemerintah Kota Denpasar memang dibebankan dana yang besar dalam pelaksanaan program tersebut, namun bila dibandingkan anggaran untuk pengobatan DBD jika kasusnya meledak diperkirakan akan jauh lebih besar. Contohnya, pada tahun 2010 di Kota Denpasar kasusnya sempat meningkat drastis menjadi 4.431 kasus dengan 41 kematian. Saat ini, kasusnya sudah jauh menurun setelah program jumantik ini berjalan lebih dari 2 tahun. ${ }^{14}$

Perilaku sebagian besar masyarakat Indonesia belum didasari kesadaran akan pentingnya memelihara kebersihan lingkungan. Salah satu masalah yang umum ditemukan adalah rendahnya kesadaran penduduk untuk melakukan 3M Plus secara rutin. Pada beberapa daerah tertentu ketersediaan air bersih tidak teratur (sulit) sehingga penduduk terbiasa menampung air bersih di dalam drum dan air ditampung untuk jangka waktu lama. Oleh karena jarang dikuras, drum tersebut menjadi tempat berkembang biak Aedes aegypti. Sementara itu, di daerah dengan ketersediaan air yang baik penduduk juga menampung air untuk keperluan mandi, cuci, dan kakus (MCK). Slogan 3M Plus ternyata masih belum terakulturasi dengan kebiasaan masyarakat sehari-hari karena 
terbentur masalah teknis di lapangan sehingga selama ini terkesan masih sebatas slogan dan belum membudaya dalam masyarakat. ${ }^{11}$

Pola kelakuan adalah proses perubahan dari cara bertingkah laku yang diciptakan untuk ditiru oleh banyak orang. Proses perubahan dari cara bertindak menjadi pola bertindak tetap melalui proses pergaulan (peniruan) yang dilakukan oleh banyak orang dalam waktu relatif lama sehingga terbentuklah suatu kebiasaan. ${ }^{16}$ Perbedaan kondisi kota dan desa sangat berpengaruh pada pembentukan perilaku masing-masing individu. Masyarakat kota cenderung dinamis dan mudah menerima kebiasaaan-kebiasaan baru sepanjang hal tersebut dapat diterima secara rasional dan tidak merugikan secara ekonomi. Berbeda dengan masyarakat desa yang dipengaruhi oleh nilai, norma, dan adat istiadat yang masih kuat sehingga arus perubahan terhadap kebiasaan baru cenderung lebih lambat. ${ }^{17}$ Salah satu antisipasi mewabahnya DBD adalah dengan memantau keberadaan jentik nyamuk di lingkungan sekitar rumah warga. Untuk itu, kelurahan atau dinas kesehatan mengerahkan jumantik. Sebuah survei di 6 kota besar (Makasar, Yogyakarta, Bandung, Jakarta, dan Medan) menunjukkan mayoritas responden $61 \%$ mengaku tidak ada satu pun petugas dari kelurahan atau dinas kesehatan yang datang ke rumah-rumah sekitar mereka untuk memantau jentik nyamuk. ${ }^{18}$

Berdasarkan hasil penelitian terhadap partisipasi kader jumantik di Kabupaten Boyolali diperoleh hasil ada hubungan antara tingkat pendidikan responden, tingkat penghasilan, serta jenis pekerjaan dengan partisipasi kader jumantik dalam pemberantasan DBD. ${ }^{19}$ Hasil ini senada dengan hasil penelitian Achmad bahwa pengetahuan, adanya anjuran serta kunjungan petugas kesehatan ke rumah memengaruhi partisipasi ibu rumah tangga dalam kegiatan PSN DBD. ${ }^{20}$ Peran jumantik dalam sistem kewaspadaan dini DBD sangat penting dalam kegiatan pencegahan DBD. Namun, karena adanya kendala teknis serta kebiasaan masyarakat yang belum selaras dengan program PSN 3M Plus mengakibatkan hasil kinerja jumantik belum memperlihatkan hasil yang optimal. Meskipun demikian, peran jumantik dalam menurunkan angka kasus DBD dapat dioptimalkan. Namun hal ini sangat membutuhkan komitmen khusus dari para pemangku kebijakan dari tingkat atas hingga tingkat bawah di era desentralisasi ini untuk membangun sistem kewasapadaan dini yang lebih baik. ${ }^{18}$ Saat ini, diperlukan pengubahan pemahaman kesehatan lama yang mengutamakan pelayanan kesehatan bersifat kuratif dan rehabilitatif menjadi paradigma sehat yang bersifat proaktif. Paradigma sehat yang proaktif sebagai model pembangunan kesehatan diharapkan mampu menciptakan masyarakat mandiri dalam menjaga kesehatan melalui kesadaran yang lebih tinggi pada pen- tingnya pelayanan kesehatan yang bersifat promotif dan preventif. Program penanggulangan DBD dalam paradigama ini lebih mengutamakan upaya promotif dan preventif termasuk peningkatan kapasitas petugas/kader kesehatan (termasuk jumantik) sebagai pintu masuk utama dalam meningkatkan pemahaman epidemiologi penyakit yang berbahaya ini.

\section{Kesimpulan}

Berbagai upaya telah dilakukan untuk menanggulangi terjadinya peningkatan kasus, salah satu dan yang paling utama adalah dengan memberdayakan masyarakat dalam kegiatan PSN melalui gerakan 3M (menguras, menutup, mengubur). Kegiatan ini telah diintensifkan sejak tahun 1992 dan pada tahun 2000 dikembangkan menjadi 3M Plus yaitu dengan cara menggunakan larvasida, memelihara ikan, dan mencegah gigitan nyamuk. Salah satu faktor belum efektifnya pencegahan DBD di Indonesia adalah masih lemahnya sistem kewaspadaan dini. Kunci pencegahan penyakit DBD adalah pengawasan yang ketat untuk pelaporan dini hasil pemantauan kepadatan vektor. Peran jumantik sangat penting dalam sistem kewaspadaan dini DBD karena berfungsi untuk memantau keberadaan serta menghambat perkembangan awal dari vektor penular DBD. Keaktifan kader jumantik dalam memantau lingkungannya merupakan langkah penting untuk mencegah meningkatnya angka kasus DBD. Oleh karena itu, diperlukan upaya peningkatan keaktifan jumantik melalui motivasi yang diberikan oleh dinas kesehatan setempat.

\section{Saran}

Saran untuk para pemangku kebijakan di wilayah endemis DBD adalah untuk dapat mengevaluasi program pengendalian DBD yang selama ini telah diaplikasikan. Semoga dapat dipertimbangkan untuk merevitalisasi peran jumantik, tidak hanya sebagai pemantau jentik tetapi juga sebagai garda awal yang sesungguhnya dalam sistem kewaspadaan dini DBD. Apabila peran jumantik dapat dioptimalkan secara lebih bertanggung jawab maka potensi mewabahnya DBD dapat dikendalikan secara sistematis.

\section{Daftar Pustaka}

1. World Health Organization. Dengue and fever (dhf) vector control [homepage on the Internet]. Jeneva: World Health Organization; 1996 [cited 2012 Feb 1]. Available from: http://www.who.int/csr/ disease/dengue/en.

2. Djunaedi D. Demam berdarah (dengue dbd): epidemiologi, imunopatologi, patogenesis, diagnosis, dan penatalaksanaannya. Malang: UMM Press; 2002.

3. Kementerian Kesehatan Republik Indonesia. Data dan informasi kesehatan [homepage on the Internet]. Jakarta: Kementerian Kesehatan Republik Indonesia; 2011 [diakses tanggal 1 Maret 2012]. Diunduh 
dari: http://www.bankdata.depkes.go.id/nasional/public/report.

4. Kementerian Kesehatan Republik Indonesia. Demam berdarah dengue [homepage on the Internet]. Jakarta: Kementerian Kesehatan Republik Indonesia; 2004 [diakses tanggal 31 Juli 2011]. Diunduh dari: http://www.litbang.depkes.go.id/maskes/052004/demamberdarah1.htm.

5. Subdirektorat Pengendalian Arbovirosis, Direktorat Pengendalian Penyakit Bersumber Binatang, Direktorat Jenderal Pengendalian Penyakit dan Penyehatan Lingkungan Kementerian Kesehatan Republik Indonesia [Internet]. Informasi umum demam berdarah dengue. 2011 [diakses tanggal 4 Februari 2012]. Diunduh dari: http://www.pppl.depkes.go.id/_asset/_download/INFORMASI_UMUM_DBD_2011.pdf.

6. Yulianti NS. Pengaruh keaktifan juru pemantau jentik (jumantik) terhadap angka bebas jentik (ABJ) dan kejadian demam berdarah dengue (DBD) (studi pada pelaksanaan "gerakan jumat berseri + PSN 60 menit” di Kota Mojokerto) [tesis]. Surabaya: Universitas Airlangga; 2007.

7. Widyanti IT. Faktor-faktor yang memepengaruhi tindakan masyarakat dalam upaya pencegahan penyakit demam berdarah dengue (DBD) Desa Makam Haji Wilayah Kerja Puskesmas II Kartasura [skripsi]. Surakarta: Fakultas Kedokteran Universitas Muhammadiyah Surakarta; 2006.

8. Soeparmanto $P$, Pranata. Peningkatan penanggulangan penyakit demam berdarah dengue berbasis masyarakat dengan penyuluhan. Berita Kedokteran Masyarakat. 2006; 22 (2): 75-81.

9. Direktorat Jenderal Pengendalian Penyakit dan Penyehatan Lingkungan Kementerian Kesehatan Republik Indonesia. Petunjuk teknis penggerakan pemberantasan sarang nyamuk (PSN) demam berdarah dengue. Jakarta: Direktorat Jenderal Pengendalian Penyakit dan Penyehatan Lingkungan Kementerian Kesehatan Republik Indonesia; 1992.

10. Kompas [Internet]. Kasus DBD di Indonesia tertinggi di ASEAN. Edisi 9 Februari 2011 [diakses tanggal 1 Desember 2011]. Diunduh dari: http://www.health.kompas.com/read/2011/02/19/07163187/Kasus.D BD.di.Indonesia.Tertinggi.di.ASEAN.

11. Sungkar S. Pemberantasan demam berdarah dengue: sebuah tantangan yang harus dijawab. Majalah Kedokteran Indonesia. 2007; 57 (6): 167 -70 .

12. Organisasi.Org [Internet]. Cara jumantik memberantas nyamuk demam berdarah dengue (DBD): pengertian juru pemantau jentik. 2009 [diakses tanggal 14 Maret 2012]. Diunduh dari: http://www.organisasi.org/ cara-jumantik-memberantas-nyamuk-demam-berdarah-dengue-dbdpengertian-juru-pemantau-jentik.

13. Direktorat Jenderal Pengendalian Penyakit dan Penyehatan Lingkungan Kementerian Kesehatan Republik Indonesia. Pencegahan dan pemberantasan demam berdarah dengue di Indonesia. Jakarta: Direktorat Jenderal Pengendalian Penyakit dan Penyehatan Lingkungan Kementerian Kesehatan Republik Indonesia; 2005.

14. Purnama SG. Program jumantik dan keberhasilannya cegah DBD [Internet]. 2011 [diakses tanggal 1 Maret 2012]. Diunduh dari: http://www.purnamabagus.blogspot.com/2011/12/program-jumantikdan-keberhasilannya.html.

15. Sungkar S, Widodo AD, Suartanu N. Evaluasi program pemberantasan demam berdarah dengue di Kecamatan Pademangan Jakarta Utara. Majalah Kedokteran Indonesia. 2006; 56: 108-12.

16. Notoatmodjo S. Pendidikan dan perilaku kesehatan. Jakarta: Penerbit Rineka Cipta; 2003. hal: 114-34.

17. Sarwono S. Sosiologi kesehatan beberapa konsep beserta aplikasinya. Yogyakarta: Gadjah Mada University Press; 2007. hal. 30-40.

18. Media Indonesia. Penanganan wabah DBD 2007, kinerja pemerintah tidak memuaskan [Internet]. Edisi 20 Februari 2008 [diakses tanggal 14 Februari 2012]. Diunduh dari: http://www.prakarsa-rakyat.org/artikel/opini/artikel_cetak.php?aid=25165.

19. Pambudi. Faktor-faktor yang mempengaruhi partisipasi kader jumantik dalam pemberantasan DBD di Desa Ketitang Kecamatan Nogosari Kabupaten Boyolali tahun 2009 [skripsi]. Surakarta: Fakultas Kesehatan Masyarakat Universitas Muhammadiyah Surakarta; 2009.

20. Achmad HH. Variabel yang mempengaruhi partisipasi ibu rumah tangga dalam pelaksanaan pemberantasan sarang nyamuk. Jurnal Cermin Dunia Kedokteran.1997; 199: 9-12. 